\title{
Above and Belowground Growth of Corymbia maculata in a Constructed Soil: The Effect of Profile Design and Organic Amendment
}

\author{
Karen Smith, Peter May, and Robert White
}

\begin{abstract}
Spotted gum (Corymbia maculata (Hook.) K.D. Hill \& L.A.S. Johnson), a common street tree in southern Australian cities, was used to assess growth responses to variations in profile design and organic amendment of constructed soils. Aboveground growth responses were total stem dry weight and foliar nutrient content. The belowground response was root length density. Soil profiles were constructed of sand, amended with either coir fiber, composted biosolids or composted green waste, at rates of $0,5,10$ or $20 \%$ by volume. The profiles were either layered, with a $150 \mathrm{~mm}$ (6 in) organic-amended surface layer, or uniform, with amendment of the entire profile. A single fertilizer treatment was applied to all profiles. Shoot dry weight was only affected by organic matter type with the greatest growth in sand amended with composted biosolids. Foliage $\mathrm{P}$ and $\mathrm{K}$ content were affected by amendment but foliage $\mathrm{N}$ was not. Profile design affected root length density and distribution. Trees in uniform profiles had greater root length density, and a more uniform distribution of roots, especially with compost amendments. Above- and belowground growth increases are thought to be due to increased nutrient status resulting from organic matter mineralization.

Key Words. Biosolids; Coir Fiber; Compost; Designed Soils; Root Density; Soil Amendment.
\end{abstract}

Continued development of urban land often results in depleted soil resources for tree growth. In cases where the existing soil resource is severely degraded or where no native soil exists, replacement soil profiles must be specified and constructed (Craul and Craul 2006). In many applications of this type, relatively coarse-textured soils are used because they provide reasonable drainage and because they can resist the compaction that inevitably occurs during installation (Lichter and Lindsey 1994; Kelsey 1998; Craul 1999). The poor nutrient retention of sands may be an issue in subsequent tree performance in these applications and supplementation of the sand with organic matter is one approach used to address this potential problem. However, the use of large quantities of organic matter in constructed soils can lead to problems of soil volume loss associated with decomposition, Craul (1999) suggests "conservative" upper limits of organic matter incorporation of $20 \%-25 \%$ by volume to address this issue. High organic matter content can also lead to the development of anaerobic conditions in the profile, severely affecting tree establishment (Burnett 1991; Craul 1999). The current Australian Standard for constructed landscape soils (AS 4419-2003) (Standards Australia 2003a) makes recommendations on the quantities and depths of mixing of organic materials to try and prevent this phenomenon. There is a paucity of research on many aspects of the urban horticulture of Australian species, including their growth in constructed soil profiles. This paper describes part of a larger study (Smith 2003) carried out to assess the performance of a commonly-grown Australian urban tree species (spotted gum Corymbia maculata (Hook.) K.D. Hill \& L.A.S. Johnson) in constructed profiles. The larger study addressed both tree nutrition in sandy constructed soils and the effect of soil profile design variables on tree growth above and below ground. This paper reports the findings of an experiment that examined, under a single fertilizer regime, the effects of organic matter type, concentration and distribution in the profile on tree shoot growth, and on the growth and distribution of tree roots within the soil profile. The results of this experiment will assist decision making when specifying new soil profiles for trees.

\section{MATERIALS AND METHODS}

The experiment was a randomized complete block factorial design where a basal root zone medium of sand was modified with three treatment factors: organic matter type (three types), concentration of added organic matter (three levels), and profile design (layered or uniform). In addition, there was an unamended sand treatment as a control. Each treatment occurred once in each of the three blocks. The soil profiles were constructed in uPVC stormwater pipe of internal diameter $220 \mathrm{~mm}$ ( 9 in), cut into $650 \mathrm{~mm}$ (26 in) lengths.

The sand was a poorly-graded sand of the type used for sports turf construction. Particle size was measured by a sieve analysis (Table 1).

Table 1. Sieve analysis of the sand used in profile construction.

\begin{tabular}{lc}
\hline $\begin{array}{l}\text { Sieve size } \\
(\mathrm{mm})\end{array}$ & $\begin{array}{l}\text { Percentage retained } \\
\text { (by weight) }\end{array}$ \\
\hline 2.00 & 0.7 \\
1.00 & 3.0 \\
0.71 & 10.0 \\
0.50 & 52.9 \\
0.25 & 21.3 \\
0.106 & 10.6 \\
Dust $(<0.106)$ & 1.5 \\
\hline
\end{tabular}




\section{Experimental Profiles}

Three types of organic matter, coir fiber, composted green waste and composted biosolids were evaluated. Each was used as a soil amendment at the rates of 5, 10, and $20 \%$ by volume. Coir fiber is a product of the husk of the coconut, and is also known as coir fiber dust. It is used as a peat replacement in nursery media (Offord et al. 1998) and has been used in constructed landscape soils. The composted green waste was commercially composted to meet the criteria of Australian Standard 4434-2003 Mulches, composts and soil conditioners (Standards Australia 2003b). The composted biosolids met the Class A requirements of the United States Environment Protection Authority (1993) biosolids standards, and the AS 4454-2003 requirements for pasteurization. Both the composted green waste and composted biosolids were passed through a $5 \mathrm{~mm}(0.2 \mathrm{in})$ screen before use.

The other factor was profile design where the three organic amendments were either restricted to the surface $150 \mathrm{~mm}$ (6 in) of the profile (layered profile) or mixed through the entire profile (uniform profile). In each design the organic amendment of the treated soil was at the three rates given above. The soil mixes were prepared in $50 \mathrm{~L}$ (13 gal) batches in a concrete mixer. Trace elements $\left(0.8 \mathrm{~kg} \mathrm{~m}^{-3}\right.$ Micromax, Scott's Australia, Baulkham Hills, NSW) and ground dolomite $\left(1 \mathrm{~kg} \mathrm{~m}^{-3}\right)\left(0.5\right.$ and $0.6 \mathrm{lb} \mathrm{ft}^{-3}$ respectively) were mixed in at this stage, prior to profile construction.

\section{Profile Construction}

A $25 \mathrm{~mm}$ layer of $4-5 \mathrm{~mm}$ angular gravel was placed in the bottom of each container as a filter and drainage layer. The sand or sand/organic mixes were placed in the containers in $150 \mathrm{~mm}$ layers, and each layer was lightly compressed manually. The total depth of root zone was $600 \mathrm{~mm}$ (24 in), with a $25 \mathrm{~mm}$ deep irrigation volume left at the top of all planters to facilitate irrigation by micro-sprays. After filling, the planters were irrigated several times to fully consolidate the constructed profile prior to planting. The bulk density of the constructed profiles ranged from $1.9 \mathrm{Mg} \mathrm{m}^{-3}$ (3200 $\left.\mathrm{lb} \mathrm{yd}^{-3}\right)$ for the unamended sand to $1.5 \mathrm{Mg}$ $\mathrm{m}^{-3}\left(2530 \mathrm{lb} \mathrm{yd}^{-3}\right)$ for sands amended with $20 \%$ organic matter.

\section{Planting Stock, Planting and Maintenance}

Five-month old $C$. maculata seedling liners were purchased in square containers [ $50 \mathrm{~mm}$ wide x $130 \mathrm{~mm}$ ( 2 in x 5 in) deep]. They were selected for the experiment based on their uniformity of root system development, size, and leaf morphology. Relatively small plants were used because of the restricted volume of the experimental system. A single nutrition treatment was surface applied to all constructed profiles after planting. The slow release fertilizer Once High Fine N (11:1:4) (Scott's Australia) was used. This fertilizer was reapplied four months later at the same rate giving total N, P and K applications the equivalent of 1000, 90, and 340 $\mathrm{kg} \mathrm{ha}^{-1}\left(890,80\right.$, and $\left.300 \mathrm{lb} \mathrm{ac}^{-1}\right)$ respectively. These rates were based on growth responses observed in an initial experiment that evaluated nutrient responses in C. maculata growing in a sand profile with the surface $150 \mathrm{~mm}$ amended with coir fiber (Smith 2003). In greenhouse experiments to evaluate nutrient responses in forestry eucalypts, Olsen and Bell (1990) used an upper rate of $200 \mathrm{~kg} \mathrm{~N} \mathrm{~kg} \mathrm{ha}^{-1}\left(180 \mathrm{lb} \mathrm{N} \mathrm{ac}^{-1}\right)$ in a clay loam soil, and Bennett et al. (1996) an upper rate of $400 \mathrm{~kg} \mathrm{~N} \mathrm{ha}^{-1}\left(360 \mathrm{lb} \mathrm{N} \mathrm{ac}^{-1}\right)$ in a clay soil. The higher fertilizer used in this experiment was due to the low fertility of the sandy soil. Initial fertilizer recommen- dations for plantation eucalypts planted in sandy soil in western Australia are as high as $18 \mathrm{~g} \mathrm{~N}(0.63 \mathrm{oz} \mathrm{N})$ per tree (Cromer 1996) compared to the $3.9 \mathrm{~g} \mathrm{~N}(0.14 \mathrm{~g} \mathrm{~N})$ per tree applied in this experiment. The experiment was conducted over the spring and early summer with the trees planted in the containers on August 2, 2000, and harvested on January 2, 2001. During the experiment the trees were irrigated with a microirrigation system controlled with a timer, as required to maintain soil moisture. All blocks and containers received the same irrigation treatment. The trees were grown outdoors in a nursery in Richmond, VIC, Australia.

\section{Aboveground Growth Measurements}

At the conclusion of the experiment, samples of youngest fully expanded leaves were harvested for foliar nutrient analysis. The harvested leaves were dried at $80^{\circ} \mathrm{C}\left(176^{\circ} \mathrm{F}\right)$ to constant weight for subsequent tissue analysis. Each seedling was then cut off at ground level, or just above the lignotuber if one was present, and the entire seedling top dried at $80^{\circ} \mathrm{C}$ to constant weight. Reported total shoot dry weights include the weights of leaves harvested for nutrient analysis.

\section{Chemical Methods for Analysis of Leaf Tissue and Organic Amendments}

Samples were oven-dried, ground to a fine powder and total $\mathrm{N}$ was measured using a Carlo Erba NA 1500 analyser (Carlo Erba now Thermo Electric, Milano, Italy). Total P was measured by colorimetric analysis based on the reaction of soluble orthophosphate with molybdate-vanadate (Olsen and Dean 1965) in digests of finely ground samples prepared using Piper's (1950) method, modified to omit perchloric acid, at high temperature $\left[200-350^{\circ} \mathrm{C}\left(392-662^{\circ} \mathrm{F}\right)\right]$. Total $\mathrm{K}$ was measured in the same acid digests by diluting to an appropriate range and analyzing with a Varian SpectrAA 200 atomic absorption spectrophotometer (Varian Australia, Mulgrave, VIC, Australia) in flame photometry mode (Knudsen et al. 1982).

\section{Root Density Measurements}

At the conclusion of the experiment, roots were harvested at three sample depths in each soil profile, to the east side of the transplanted root ball, using a metal core sampler [ $150 \mathrm{~mm}$ long x $25 \mathrm{~mm}$ (6 in x 1 in) diameter]. The first core was taken at the surface [0-150 mm (0-6 in)], the second from 180-330 mm (7-13 in), and the third from $350-500 \mathrm{~mm}$ (14-20 in). The core samples were washed through a series of sieves and the roots recovered. Root length was measured using a desktop scanner in conjunction with Rhizo V 4.1 software (Regent Instruments, Québec, Canada). The total root length in the samples at each depth was converted to root length density $\left(\mathrm{L}_{\mathrm{v}} \mathrm{cm} \mathrm{cm}^{-3}\right)$ by dividing by the core volume, which had been calculated from the dimensions of the sampler.

\section{Statistical Analysis (Shoot and Root Growth)}

The unamended sand treatment could not be included in ANOVAs because of incomplete replication, hence the analysis of the data was done in two stages. First, an ANOVA was performed using all the fully replicated treatments. Means comparisons were made using Fisher's least significant difference $(P<0.05)$. Then, to allow comparison of the unamended sand treatment with the organic-amended treatments, Dunnett's multiple comparisons with 
the unamended sand as a control was used. If a significant treatment effect was found, Dunnett's paired t-tests $(P<0.05)$ were then performed comparing the control with each treatment mean, adjusting for multiple comparisons. Minitab V. 12.0 statistical software (Minitab Inc., State College, PA) was used for all these analyses. Since the shoot dry weight and root density data was not normally distributed, a $\log _{\mathrm{e}}$ transformation was performed and comparisons of treatment effects using ANOVA were done using this transformed data. Where transformation was used the tables of means show the back-transformed data. Since the assumptions for ANOVA were met for all foliar data sets, these data were analyzed on the original scale of measurement. There were no significant three way interactions and no significant blocking effects.

\section{RESULTS}

\section{Shoot Dry Weight}

Only the main effect organic matter type had a significant effect on shoot dry weight (Table 2). The trend for shoot dry weight in response to organic matter type was composted biosolids $>$ green waste $>$ coir. All treatment means were significantly different. However, Dunnett's multiple comparisons showed that the shoot dry weights of seedlings growing in unamended sand, while greater than in coir-amended sand and less than in sand amended in either compost, was not significantly different from any of those treatments.

Table 2. The effect of organic matter type on shoot dry weight of C. maculata (back-transformed means).

\begin{tabular}{|c|c|c|c|}
\hline \multirow[b]{2}{*}{ Organic matter } & \multicolumn{3}{|c|}{ Shoot dry wt $(\mathrm{g})^{\mathrm{z}}$} \\
\hline & Coir & $\begin{array}{l}\text { Composted } \\
\text { biosolids }\end{array}$ & $\begin{array}{l}\text { Composted } \\
\text { green waste }\end{array}$ \\
\hline $\operatorname{Mean}^{y}$ & $58.6 \mathrm{c}$ & $91.8 \mathrm{a}$ & $78.3 b$ \\
\hline \multicolumn{4}{|c|}{$\begin{array}{l}\text { Trees planted in August 2000; the experiment concluded in January } 2001 . \\
\text { Means are from three replications. } \\
{ }^{\mathrm{y}} \text { Means followed by the same letter are not significantly different }(P<0.05) \text {. } \\
\text { Since the means are back-transformed no SE values are shown. Mean shoot dry } \\
\text { wt in unamended sand }=66.0 \mathrm{~g} \text {. }\end{array}$} \\
\hline
\end{tabular}

\section{Foliar Nutrient Responses}

\section{Nitrogen}

There was no significant effect of profile design, organic matter type, and organic matter concentration, or any interactions between these factors on foliar N concentrations. Dunnett's multiple comparisons with the control showed no significant differences of foliar $\mathrm{N}$ concentration. The values ranged from $17.9 \mathrm{mg} \mathrm{g}^{-1}(0.29$ $\left.\mathrm{oz} \mathrm{lb}^{-1}\right)$ for the control to between 14.5 and $22.6 \mathrm{mg} \mathrm{g}^{-1}(0.23-0.36$ $\mathrm{oz} \mathrm{lb}^{-1}$ ) for amended sands. All values of foliar $\mathrm{N}$ were in the marginal to adequate range for C. maculata (Dell and Robinson 1993).

\section{Phosphorus}

The ANOVA for foliar P concentration showed that there were significant interactions between organic matter type and concentration, and profile design and organic matter type (Table 3; Table 4). Dunnett's multiple comparisons with the control showed significantly less foliar P in seedlings grown in unamended sand than in uniform profiles amended with $5 \%$ or $10 \%$ composted biosolids. Composted biosolids amendment at $10 \%$ had the greatest effect on foliar P. Coir amendment resulted in significantly lower foliar
P than any of the composted biosolids or green waste concentrations. Foliar P concentrations were not significantly different for composted biosolids amended at 5\% and green waste amendment at $10 \%$. All foliar P concentrations were in the adequate concentration range (Dell and Robinson 1993). Sand amendment with composted biosolids or green waste resulted in significantly greater foliar $\mathrm{P}$ than with coir. Foliar $\mathrm{P}$ was significantly greater in uniform profiles than layered for composted biosolids and green waste amendment but was not affected by profile design with coir amendment (Table 4). All of these means were in the adequate range for foliar P concentration (Dell and Robinson 1993).

Table 3. The effect of the interaction between organic matter type and concentration on foliar $\mathrm{P}$ concentration of c. maculata.

\begin{tabular}{llll}
\hline & \multicolumn{3}{c}{ Foliar P concentration $\left(\mathrm{mg} \mathrm{g}^{-1}\right)^{\mathrm{z}}$} \\
\cline { 2 - 4 } $\begin{array}{l}\text { Organic } \\
\text { matter \% }\end{array}$ & Coir & $\begin{array}{l}\text { Composted } \\
\text { Biosolids }\end{array}$ & $\begin{array}{l}\text { Composted } \\
\text { green waste }\end{array}$ \\
\hline $5^{\mathrm{y}}$ & $2.5(0.1) \mathrm{e}$ & $4.3(0.7) \mathrm{b}$ & $3.7(0.2) \mathrm{c}$ \\
10 & $2.5(0.2) \mathrm{e}$ & $5.0(0.9) \mathrm{a}$ & $4.20 .8) \mathrm{b}$ \\
20 & $3.0(0.2) \mathrm{d}$ & $3.8(0.4) \mathrm{c}$ & $2.8(0.2) \mathrm{d}$ \\
\hline
\end{tabular}

${ }^{\mathrm{z}}$ Trees planted in August 2000; the experiment concluded in January 2001. Means are from three replications, standard error in parentheses.

${ }^{y}$ Means in the table followed by the same letter are not significantly different $(P<0.05), \mathrm{LSD}=0.3$.

Mean foliage $\mathrm{P}$ in unamended sand $=2.8 \mathrm{mg} \mathrm{g}^{-1}$.

Table 4. The effect of the interaction between profile design and organic matter type on foliar $\mathrm{P}$ concentration of C. maculata.

\begin{tabular}{llll}
\hline \multirow{2}{*}{ Profile design } & \multicolumn{3}{c}{ Foliar P concentration $\left(\mathrm{mg} \mathrm{g}^{-1}\right)^{\mathrm{z}}$} \\
\cline { 2 - 4 } & Coir & $\begin{array}{l}\text { Composted } \\
\text { biosolids }\end{array}$ & $\begin{array}{l}\text { Composted } \\
\text { green waste }\end{array}$ \\
\hline Layered profile $^{\mathrm{y}}$ & $2.8(0.1) \mathrm{c}$ & $3.1(0.2) \mathrm{c}$ & $2.8(0.3) \mathrm{c}$ \\
Uniform profile & $2.8(0.2) \mathrm{c}$ & $5.6(0.5) \mathrm{a}$ & $4.4(0.4) \mathrm{b}$ \\
\hline
\end{tabular}

${ }^{z}$ Trees planted in August 2000; the experiment concluded in January 2001.

Means are from 6 replications, standard error in parentheses.

y Means in the table followed by the same letter are not significantly different $(P<0.05), \mathrm{LSD}=0.4$

Mean foliage $\mathrm{P}$ in unamended sand $=2.8 \mathrm{mg} \mathrm{g}^{-1}$.

\section{Potassium}

TheANOVA for foliar K concentration showed that only the effect of organic matter type was significant (Table 5). Dunnett's test showed no significant differences between the control and the treatment means for foliar $\mathrm{K}$. The highest concentrations of foliar K occurred with the two compost amendment, which resulted in significantly higher foliage $\mathrm{K}$ than coir amendment The values were in the deficient range for foliar K concentration (Dell and Robinson 1993).

Table 5. The effect of organic matter type on foliar $\mathrm{K}$ of C. maculata.

\begin{tabular}{|c|c|c|c|}
\hline \multirow[b]{2}{*}{ Organic matter type } & \multicolumn{3}{|c|}{ Foliar $\mathrm{K}$ concentration $\left(\mathrm{mg} \mathrm{g}^{-1}\right)^{\mathrm{z}}$} \\
\hline & Coir & $\begin{array}{l}\text { Composted } \\
\text { biosolids }\end{array}$ & $\begin{array}{l}\text { Composted } \\
\text { green waste }\end{array}$ \\
\hline Mean $^{y}$ & $2.8(0.2) \mathrm{b}$ & $3.6(0.3) \mathrm{a}$ & $3.5(0.1) \mathrm{a}$ \\
\hline \multicolumn{4}{|c|}{$\begin{array}{l}\text { Trees planted in August 2000; the experiment concluded in January } 2001 \text {. } \\
\text { Means are from nine replications, standard error in parentheses. } \\
\text { Means followed by the same letter are not significantly different }(P<0.05) \text {, } \\
\text { LSD }=0.4 \text {. } \\
\text { Mean foliage } \mathrm{K} \text { in unamended sand }=3.1(0.4) \mathrm{mg} \mathrm{g}^{-1} \text {. }\end{array}$} \\
\hline
\end{tabular}




\section{Root growth}

There were significant interactions between sample depth and organic matter type, and sample depth and profile design (Table 6; Table 7). In the surface sample root length density was higher in sand amended with biosolids or green waste composts than with coir but the differences were not significant. In sand amended with the biosolids and green waste composts, there were no significant differences between root density at the three sampling depths. In sand amended with coir, $\mathrm{L}_{\mathrm{v}}$ decreased with depth, with significantly lower mean density at each sampling depth down the profile. In the layered profiles, there were significant decreases in $\mathrm{L}_{\mathrm{V}}$ with depth, but in the uniform profiles, $\mathrm{L}_{\mathrm{v}}$ did not change with sample depth.

To further explain the effects of the organic amendments on root growth, mean $L_{\mathrm{v}}$ was examined at each sample depth. In this analysis, the unamended sand treatment was included for comparison.

\section{Surface Sample (0-150 mm (0-6 in))}

Dunnett's multiple comparisons showed that $L_{\mathrm{V}}$ in unamended sand was not significantly different to that found in any of the amended sands. The ANOVA showed no significant main effects, or significant interactions between factors. The back transformed mean $L_{\mathrm{v}}$ in the unamended sand was $3.1 \mathrm{~cm} \mathrm{~cm}^{-3}$ (20 in $\mathrm{in}^{-3}$ ) and the range of values of $L_{\mathrm{V}}$ for the treatment combinations was from 2.1 to $6.4 \mathrm{~cm} \mathrm{~cm}^{-3}\left(13.6-41.3 \mathrm{in} \mathrm{in}^{-3}\right)$.

Table 6. The effect of the interaction between sample depth and organic matter type on root density of C. maculata (back-transformed means).

\begin{tabular}{llll}
\hline & \multicolumn{3}{c}{ Root density $\left(\mathrm{cm} \mathrm{cm}^{-3}\right)^{\mathrm{z}}$} \\
\cline { 2 - 4 } $\begin{array}{l}\text { Sample depth } \\
(\mathrm{mm})\end{array}$ & Coir & $\begin{array}{l}\text { Composted } \\
\text { biosolids }\end{array}$ & $\begin{array}{l}\text { Composted } \\
\text { green waste }\end{array}$ \\
\hline $0-150^{\mathrm{y}}$ & $2.0 \mathrm{a}$ & $2.4 \mathrm{a}$ & $2.8 \mathrm{a}$ \\
$180-330$ & $1.2 \mathrm{~b}$ & $2.4 \mathrm{a}$ & $2.4 \mathrm{a}$ \\
$350-500$ & $0.8 \mathrm{c}$ & $2.2 \mathrm{a}$ & $2.2 \mathrm{a}$ \\
\hline
\end{tabular}

${ }^{\mathrm{z}}$ Trees planted in August 2000; the experiment concluded in January 2001. Means are from three replications.

${ }^{y}$ Means in the table followed by the same letter are not significantly different $(P<0.05)$.

Table 7. The effect of the interaction between sample depth and profile design on root density of $C$. maculata (backtransformed means).

\begin{tabular}{lll}
\hline & \multicolumn{2}{c}{ Root density $\left(\mathrm{cm} \mathrm{cm}^{-3}\right)^{\mathrm{z}}$} \\
\cline { 2 - 3 } $\begin{array}{l}\text { Sample depth } \\
(\mathrm{mm})\end{array}$ & Layered profiles & Uniform profiles \\
\hline $0-150$ & $2.5 \mathrm{a}$ & $2.2 \mathrm{a}$ \\
$180-330$ & $1.6 \mathrm{~b}$ & $2.4 \mathrm{a}$ \\
$350-500$ & $0.9 \mathrm{c}$ & $2.7 \mathrm{a}$ \\
\hline
\end{tabular}

${ }^{\mathrm{z}}$ Trees planted in August 2000; the experiment concluded in January 2001.

Means are from three replications.

${ }^{y}$ Means in the table followed by the same letter are not significantly different $(P<0.05)$.

\section{Sample Depth $180-330 \mathrm{~mm}$ (7-13 in)}

As at the surface, Dunnett's test showed no significant differences between the means of $\mathrm{L}_{\mathrm{V}}$ for the unamended sand and any organic amended sand. The ANOVA for the factors considered alone found that the main effects organic matter type and profile design had significant effects on $\mathrm{L}_{\mathrm{v}}$, but organic matter concentration had no effect. There were no significant interac- tions between treatment combinations (Table 8). At this sampling depth, $\mathrm{L}_{\mathrm{V}}$ was significantly greater in the uniform profiles than in the layered profiles. $\mathrm{L}_{\mathrm{v}}$ in sand amended with biosolids or green waste composts had significantly greater root density than sand amended with coir but there was no difference between root density in sand amended with either compost.

Table 8. The effects of organic matter type and profile design on root density of $C$. maculata at sample depth 180 $330 \mathrm{~mm}$ (7-13 in) (back-transformed means).

\begin{tabular}{lllll}
\hline & \multicolumn{4}{c}{ Root density $\mathrm{L}_{\mathrm{v}}\left(\mathrm{cm} \mathrm{cm}^{-3}\right)^{\mathrm{z}}$} \\
\cline { 2 - 5 } & Coir & $\begin{array}{l}\text { Composted } \\
\text { biosolids }\end{array}$ & $\begin{array}{l}\text { Composted } \\
\text { green waste }\end{array}$ & $\begin{array}{l}\text { Overall } \\
\text { mean }^{\mathrm{y}}\end{array}$ \\
\hline Layered profiles & 2.3 & 2.9 & 2.7 & $2.6 \mathrm{~b}$ \\
Uniform profiles & 2.3 & 4.5 & 5.0 & $3.9 \mathrm{a}$ \\
Overall mean & $2.3 \mathrm{~b}$ & $3.7 \mathrm{a}$ & $3.8 \mathrm{a}$ & \\
\hline
\end{tabular}

${ }^{\mathrm{z}}$ Trees planted in August 2000 and the experiment concluded in January 2001 Means are from six replications.

y Overall means followed by the same letter down the column and across the row are not significantly different $(P<0.05)$.

Mean root density in unamended sand $=2.9 \mathrm{~cm} \mathrm{~cm}^{-3}$.

\section{Sample Depth 350-500 mm (14-20 in)}

As at the other two sample depths, Dunnett's test showed no significant differences between root densities in unamended sand and the amended sands. The ANOVA for the factors considered alone showed that the main effects profile design and organic matter type had significant effects, that organic matter concentration was not a significant factor and that there were no interactions (Table 9). Root density was significantly greater in the uniform profiles at sample depth 350-500 $\mathrm{mm}$ than in the layered profiles. The overall response of root density to organic matter type was the same as at sample depth 180-330 mm with greater $\mathrm{L}_{\mathrm{V}}$ with biosolids or green waste compost amendment than with coir. There was however, no significant difference between responses to biosolids or green waste composts.

Table 9. The effect of organic matter type and profile design on root density of $C$. maculata at sample depth $350-500 \mathrm{~mm}$ (14-20 in) (back-transformed means).

\begin{tabular}{lllll}
\hline & \multicolumn{4}{c}{ Root density $\mathrm{L}_{\mathrm{v}}\left(\mathrm{cm} \mathrm{cm}^{-3}\right)^{\mathrm{z}}$} \\
\cline { 2 - 5 } & Coir & $\begin{array}{l}\text { Composted } \\
\text { biosolids }\end{array}$ & $\begin{array}{l}\text { Composted } \\
\text { green waste }\end{array}$ & $\begin{array}{l}\text { Overall } \\
\text { mean }^{\mathrm{y}}\end{array}$ \\
\hline Layered profile & 1.6 & 2.5 & 2.5 & $2.2 \mathrm{~b}$ \\
Uniform profile & 2.2 & 5.5 & 5.0 & $4.2 \mathrm{a}$ \\
Overall mean & $1.9 \mathrm{~b}$ & $4.0 \mathrm{a}$ & $3.7 \mathrm{a}$ & \\
\hline
\end{tabular}

z Trees planted in August 2000; the experiment concluded in January 2001.

Means are from six replications.

${ }^{y}$ Overall means followed by the same letter down the column and across the row are not significantly different $(P<0.05)$.

Mean root density in unamended sand $=2.3 \mathrm{~cm} \mathrm{~cm}^{-3}$.

\section{DISCUSSION}

Shoot dry weight was affected by the type of organic matter used for soil amendment. The two composts resulted in greater shoot dry weight than the coir fiber. Neither the amount of organic matter nor the design of the profile had significant effects on shoot dry weight. Foliar $\mathrm{N}$ was not influenced by any treatment but foliar $\mathrm{P}$ and foliar $\mathrm{K}$ were. Composted biosolids amendment increased foliar P and composted green waste amendment increased foliar K. 
Root densities at different sample depths were affected by organic matter type and profile design. In surface samples, organic matter type had no significant effect on root density although mean root density was higher with compost amendment than with coir amendment. There was less root growth in the two deeper samples in coir amended sand than in sand amended with the two composts. In uniform profiles, root density was similar at all depths. By contrast root density was significantly lower in the deeper samples of layered profiles than at the surface. The values of root density found in this study are consistent with published data for eucalypts. Grove et al. (1996) found root densities of 1-2 $\mathrm{cm} \mathrm{cm}^{-3}\left(7-14\right.$ in in $\left.^{-3}\right)$ in Eucalyptus regnans forest in clay loam soil and $7 \mathrm{~cm} \mathrm{~cm}^{-3}\left(49 \mathrm{in} \mathrm{in}^{-3}\right)$ in E. marginata forest in sandy soil. In both cases, samples were from the surface $100 \mathrm{~mm}$ (4 in) of the profile.

The effect of organic matter type on both shoot growth and root density can partly be explained as a nutrient response due to different nitrogen, and, possibly $\mathrm{P}$, contents of the amendments used. The total $\mathrm{N}$ content of the three soil amendments was; coir fiber $4.2 \mathrm{mg} \mathrm{g}^{-1}$, biosolids $18.2 \mathrm{mg} \mathrm{g}^{-1}$, and green waste 17.3 $\mathrm{mg} \mathrm{g}^{-1}\left(0.7,2.9\right.$, and $2.8 \mathrm{oz} \mathrm{lb}^{-1}$ respectively). The total $\mathrm{P}$ content was; coir fiber $6.6 \mathrm{mg} \mathrm{g}^{-1}$, biosolids $11.8 \mathrm{mg} \mathrm{g}^{-1}$, and green waste $7.2 \mathrm{mg} \mathrm{g}^{-1}$ ( $1.1,1.9$, and $1.2 \mathrm{oz} \mathrm{lb}^{-1}$ respectively). The total $\mathrm{K}$ content was; coir fiber $2.4 \mathrm{mg} \mathrm{g}^{-1}$, biosolids $2.4 \mathrm{mg} \mathrm{g}^{-1}$, and green waste $2.9 \mathrm{mg} \mathrm{g}^{-1}\left(0.4,0.4\right.$, and $0.5 \mathrm{oz} \mathrm{lb}^{-1}$ respectively).

The carbon:nitrogen ratios of organic materials determine net $\mathrm{N}$ mineralization with $\mathrm{C}: \mathrm{N}$ ratios of $<25.0$ being sufficient to indicate net mineralization would take place (White 2006). The C:N ratios of the three organic amendments were 14.4 for composted biosolids, 13.9 for composted green waste, and 108.4 for coir.

Shoot dry weight and root growth responses in this experiment were quite similar. The greatest shoot dry weights and root densities were found in sands with composted biosolids amendment, then with composted green waste, and then with coir. Foliage $\mathrm{N}$ concentrations followed the same trends but the treatment effects were not significant. Composted biosolids amendment increased foliar P.

Shoot growth in eucalypt seedlings has been shown to be strongly responsive to available nitrogen and phosphorus levels (Olsen and Bell 1990; Bennett et al. 1996). Tree roots have been shown to increase in density in response to increased available N (Watson 1994), and thus the responses seen in this experiment are probably due to differences in $\mathrm{N}$ availability.

The lack of growth differences between trees growing in unamended sand and in sand amended with organic matter may be due to the provision of the basal slow release fertilizer program used in the experiment. An earlier experiment (Smith 2003) had shown in sand profiles shoot growth of $C$. maculata was strongly responsive to added $\mathrm{N}$ in the presence of $\mathrm{P}$. This response is seen in other eucalypt species (Olsen and Bell 1990). The high level of basal nutrition used in this experiment was presumably meeting much of the $\mathrm{N}$ demand of the seedlings with the organic treatments, possibly modifying $\mathrm{N}$ availability through nitrification of organic $\mathrm{N}$ in the two compost treatments and $\mathrm{N}$ drawdown occurring with the coir amendment. These changes to available nitrogen then influenced shoot and root growth. In coir-amended profiles, $\mathrm{N}$ drawdown at the surface may have resulted in reduced leaching of $\mathrm{N}$ to deeper parts of the profile, resulting in the lower root length densities seen at depth in these profiles.
It is interesting to note that in this experiment roots were found at all sampling depths, even at the highest levels of organic amendment. The pattern of root growth at depth seen in this study is consistent with the data of Grabosky et al. (2001), who found extensive deep root growth of three deciduous species in structural soil profiles. This they attributed to uniform density, oxygen content, and relative moisture in the structural soil profile. Anaerobic decomposition associated with soil profile construction using high levels of organic amendment of soils at depth have been reported (Burnett 1991) but the development of these conditions may be associated with poorly drained soils and/or higher levels of organic amendment than were used here. The Australian Standard for Landscape Soils (Standards Australia 2003a) recommends that organic matter not be used any deeper than $200 \mathrm{~mm}$ ( 8 in) in constructed soil profiles to avoid this risk. The results in this experiment, however, raise the possibility of organic amendment of sand profiles at depth. Composted organic matter is potentially a useful long-term source of nutrition for trees and increasing the organic content of designed soils also allows greater quantities of green waste and other compost products into landscape use. In exploring the possibility of deep mixing of organic matter, it is prudent to remember that in natural soil profiles most organic matter occurs in the surface layers of the profile, and that levels are only in the order of 3\%-5\% by weight (White 2006). It is not usual to find the high levels of organic matter used in this experiment at depth in natural soils and choice of soil matrix will be critically important in determining the performance of blended landscape soils of this type.

This study only examined the first few months of a planting and longer duration studies are required. Further work is also required to elucidate the conditions under which deep organic amendment of constructed soils is feasible. The potential for organic matter to replace soluble fertilizers in meeting early tree nutrient requirements could also be explored by using lower levels of initial fertilizer. Drainage and aeration of constructed profiles, the type of organic matter, and the quantities of organic matter incorporated are also variables that should be examined.

\section{CONCLUSIONS}

In constructed sand profiles amended with organic matter, tree shoot dry weight and root density responded to organic matter type with composted biosolids and composted green waste amendment resulting in greater shoot dry weight and root density than coir fiber. These responses are most likely due to changes in nitrogen made available for growth by these amendments as they mineralized. Root length density was greater at all depths in uniformly amended profiles than in layered ones. When unamended sand was used in the comparisons, no effects of organic matter type occurred, probably because the high rate of basal fertilizer used in this study masked nutrient release from organic matter mineralization. No evidence was found to suggest that, in coarse sands, at the experimental rates used, organic matter placed deep in a soil profile caused problems with root growth. The results of this study could be used to design tree soil profiles that would provide the work required to establish whether these responses can be repeated under urban landscape conditions. 
Acknowledgments. The authors thank Dr. Ian Gordon, Statistical Consulting Centre, The University of Melbourne, for advice regarding the statistical analysis of the data.

\section{LITERATURE CITED}

Bennett, L.T., C.J. Weston, T.S. Judd, P.M. Attiwill, and P.H. Whiteman. 1996. The effects of fertilizers on early growth and foliar nutrient concentrations of three plantation eucalypts on high quality sites in Gippsland, south eastern Australia. Forest Ecology \& Management 89:213-226.

Burnett, J. 1991. The management and rehabilitation of urban soils. In Scientific Management of Plants in the Urban Environment. T. Arthur, P. Esdale, P. May, G. Moore, J. Delpratt, and P. Kenyon (Eds). Victorian College of Agriculture and Horticulture-Burnley Campus.

Craul, P.J. 1999. Urban Soils, Applications and Practices. John Wiley and Sons Inc., New York, NY. 366 pp.

Craul, T., and P. Craul. 2006 Soil Design Protocols. John Wiley and Sons, Inc., Hoboken, NJ. 339 pp.

Cromer, R.N. 1996. Silviculture of eucalypt plantations in Australia in Nutrition of eucalypts. PM. Attiwill and M.A. Adams (Eds). CSIRO Publishing, Collingwood, VIC.

Dell, B., and J.M. Robinson. 1993. Symptoms of mineral nutrient deficiencies and the nutrient concentration ranges in seedlings of Eucalyptus maculata Hook. Plant and Soil 155:255-261.

Grabosky, J., N. Bassuk, L. Irwin, and H. van Es. 2001. Shoot and root growth of three tree species in sidewalks. Journal of Environmental Horticulture 19:206-211.

Grove, T.S., B.D. Thompson, and N. Malajczuk. 1996. Nutritional physiology of eucalypts: Uptake, distribution and utilization in Nutrition of eucalypts. P.M. Attiwill and M.A. Adams (Eds), CSIRO Publishing, Collingwood, VIC.

Kelsey, P. 1998. Soil mixes for urban sites p.154-165. In D. Neely and G.W. Watson (Eds.). The Landscape Below Ground II, Proc. Int. Workshop on Tree Root Development in Urban Soils. Vol. 2. ISA, Champaign, IL.

Knudsen, D., G. Petersen, and P. Prat 1982. Lithium, sodium and potassium. In C.A. Black, D.D. Evans, L. Ensminger, J.L. White, and F.E. Clark (Eds.). Methods of Soil Analysis. Part 2. Chemical and Microbiological Properties. American Society of Agronomy, Madison, WI.

Lichter, J., and P. Lindsay. 1994. Soil compaction and site construction: Assessment and case studies p. 126-130. In D. Neely and G.W. Watson (Eds.). The Landscape Below Ground, Proc. Int. Workshop on Tree Root Development in Urban Soils. ISA, Champaign, IL.
Offord, C., S. Muir, and J. Tyler. 1998. Growth of selected Australian plants in soilless media using coir as a substitute for peat. Australian Journal of Experimental Agriculture 38:879-887.

Olsen, J., and L. Bell. 1990. A glasshouse evaluation of "critical" N and $\mathrm{P}$ concentrations and $\mathrm{N}: \mathrm{P}$ ratios in various plant parts of six eucalypt species. Australian Journal of Botany 38:281-298.

Olsen, S.R., and L.A. Dean. 1965. Phosphorus. In Black, C.A., D.D. Evans, L. Ensminger, J.L. White, and F.E. Clark (Eds.). Methods of Soil Analysis. Part 2. Chemical and Microbiological Properties. American Society of Agronomy, Madison, WI.

Piper, C.S. 1950. Soil and plant analysis. The Waite Agricultural Research Institute, Adelaide, SA. 386 pp.

Smith, K. 2003. Th effects of properties of designed soils on the growth of Corymbia maculata. Unpublished $\mathrm{PhD}$ thesis, The University of Melbourne. 196 pp.

Standards Australia. 2003a. AS 4419 Soils for landscaping and garden use. Standards Australia, Homebush, NSW.

Standards Australia. 2003b. AS 4454 Composts, soil conditioners and mulches. Standards Australia, Homebush, NSW.

United States Environment Protection Agency. 1993. Standards for the use or disposal of composted biosolids. Final rule. 40 CFR Part 257, 403, and 503. Federal Register 58(32):9248-9415.

Watson, G. 1994. Root growth response to fertilizers. Journal of Arboriculture 20:4-8.

White, R.E. 2006. Principles and Practice of Soil Science: The Soil as a Natural Resource (Fourth Edition). Blackwell Publishing, Malden, MA. 362 pp.

Peter May (corresponding author)

University of Melbourne, Burnley Campus

Department of Resource Management and Geography

Richmond 3121, Victoria

Australia

Karen Smith

City of Hobsons Bay Parks and Recreation

Altona, Victoria

Australia

Robert White

Melbourne School of Land and Environment

University of Melbourne 
Parkville 3010, Victoria Australia

Résumé. Le Corymbia maculata, une espèce commune d'arbres le long des rues dans les villes en Australie, a été utilisé pour évaluer la réponse en terme de croissance par rapport aux variations dans le design du profil et les amendements organiques apportés aux sols construits. Au-dessus du sol, le degré de réponse a été mesuré au moyen de la masse sèche totale de la tige et du contenu foliaire en éléments minéraux. Sous le sol, cela s'est fait par la densité en longueur des racines. Les profils de sols étaient constitués de sable amendé soit de fibre de noix de coco, de bio-solides compostés ou de résidus verts compostés, le tout à des taux de $0,5,10$ ou $20 \%$ par unité de volume. Les profils étaient soient constitués en couches-avec l'amendement déposé en surface sur 15 $\mathrm{cm}$ d'épaisseur-ou uniformes avec l'amendement incorporé dans le sol. Une application de fertilisant a été faite sur chacun des profils. La masse sèche des pousses a été affectée uniquement par la matière organique, et ce avec le plus haut taux de croissance dans le sable amendé avec le compost de bio-solides. Le contenu foliaire en phosphore et potassium était affecté par la présence d'un amendement, mais pas l'azote foliaire. Le design du profil affectait la densité de l'élongation des racines ainsi que leur distribution. Les arbres dans des profils uniformes avaient une plus grande densité en longueur de racines ainsi qu'une distribution plus uniforme des racines, plus particulièrement avec les amendements à base de compost. La croissance accrue à la fois au-dessus et en-dessous du niveau du sol semblent être due à l'accroissement en éléments minéraux résultants de la minéralisation de la matière organique.

Zusammenfassung. Gefleckter Eucalyptus (Corymbia maculata (Hook.) K.D. Hill \& L.A.S. Johnson), ein häufiger Straßenbaum in südaustralischen Städten, wurde hier herangezogen, um die Wachstumsreaktionen auf verschiedene Variationen von Profilgestaltung und organischer Anreicherung der verwendeten Substrate zu untersuchen. Die oberirdischen Wachstumsreaktionen waren das totale Stammtrockengewicht und der Blattnährstoffgehalt. Die unterirdischen Reaktionen war die Wurzellängendichte. Die Bodenprofile wurden zusammeng- esetzt aus Sand, angereichert mit entweder Kokosfaser, kompostierten Bioabfällen oder kompostiertem grünen Abfall mit je 0, 5, 10 oder 20 Volumenprozent. Die Profile wurden entweder geschichtet mit einer mit organischem Materia angereicherten $15 \mathrm{~cm}$ mächtigen Oberschicht oder ein gleichförmiges, ebenfalls organisch angereichertes Substrat. Eine einzige Düngergabe wurde allen Profilen dazugegeben. Das Trockengewicht der Triebe wurde nur durch die Art des organischen Materials beeinflusst und zeigte den größten Zuwachs bei Sandsubstraten angereichert mit kompostierten Bioabfällen. Der Blattgehalt an $\mathrm{P}$ und $\mathrm{K}$ wurde durch die Anreicherung beeinflusst, aber der Stickstoffgehalt der Blätter nicht. Die Profilgestaltung beeinflusste die Wurzellängendichte und die Verteilung. Bäume in gleichförmigen Profilen hatten einen größere Wurzellängendichte und eine gleichmäßigere Verteilung ihrer Wurzeln, besonders bein Kompostzugaben. Unter- und oberirdische Wachstumssteigerungen könnten aus dem höheren Nährstoffgehalt aus der Mineralisierung der organischen Substanz herrühren.

Resumen. Fue usado el gomero manchado (Corymbia maculata (Hook.) K.D. Hill \& L.A.S. Johnson), un árbol urbano común en las ciudades sureñas de Australia, para evaluar las respuestas en crecimiento a variaciones en el diseño del perfil y el uso de mejoradores orgánicos en suelos de construcción. La respuesta en crecimiento abajo del nivel del suelo fue medida como densidad en longitud de raíces. Los perfiles de suelo fueron construidos de arena, mejorador con cualquier fibra orgánica, compuestos de biosólidos o de desechos verdes, a tasas de $0,5,10$ o $20 \%$ por volumen. Los perfiles fueron colocados en estratos, con una capa superficial de mejorador orgánico de $150 \mathrm{~mm}$ (6 in), uniforme, o con mejorador en todo el perfil. Un solo tratamiento con fertilizador fue aplicado a todos los perfiles. El peso seco de los rebrotes fue afectado solamente por el tipo de materia orgánica con el crecimiento más grande en arena mejorada con compuestos biosólidos. Los contenidos de P y K en el follaje fueron afectados por mejoradores pero el $\mathrm{N}$ no. El diseño del perfil afectó la densidad y distribución de las raíces. Los árboles en perfiles uniformes tuvieron una densidad mayor y una distribución de raíces uniforme, especialmente con mejoradores compuestos. Los incrementos en crecimiento arriba y abajo del nivel del suelo se deben al estado incrementado de elementos, resultado de la mineralización de la materia orgánica. 